\title{
Behavioral and Cerebellar Transmission Deficits in Mice Lacking the Autism-Linked Gene Islet Brain-2
}

\author{
Joanna Giza, ${ }^{1,2 \star}$ Michael J. Urbanski, ${ }^{1 \star}$ Francesca Prestori, ${ }^{3}$ Bhaswati Bandyopadhyay, ${ }^{1}$ Annie Yam, ${ }^{1}$ Victor Friedrich, ${ }^{4}$ \\ Kevin Kelley, ${ }^{4}$ Egidio D’Angelo, ${ }^{3,5}$ and Mitchell Goldfarb ${ }^{1}$ \\ ${ }^{1}$ Department of Biological Sciences, Hunter College, City University of New York, New York, New York 10065, ${ }^{2}$ Program in Biology, The Graduate Center, \\ City University of New York, New York, New York 10016, ${ }^{3}$ Department of Physiology, University of Pavia, 27100 Pavia, Italy, ${ }^{4}$ Mount Sinai School of \\ Medicine, New York, New York 10029, and ${ }^{5}$ Brain Connectivity Center, Istituto Di Ricovero e Cura a Carattere Scientifico C. Mondino, 27100 Pavia, Italy
}

Deletion of the human SHANK3 gene near the terminus of chromosome 22q is associated with Phelan-McDermid syndrome and autism spectrum disorders. Nearly all such deletions also span the tightly linked IB2 gene. We show here that IB2 protein is broadly expressed in the brain and is highly enriched within postsynaptic densities. Experimental disruption of the IB2 gene in mice reduces AMPA and enhances NMDA receptor-mediated glutamatergic transmission in cerebellum, changes the morphology of Purkinje cell dendritic arbors, and induces motor and cognitive deficits suggesting an autism phenotype. These findings support a role for human IB2 mutation as a contributing genetic factor in Chr22qter-associated cognitive disorders.

\section{Introduction}

Autism spectrum disorders (ASDs) affect approximately 1 in 160 individuals and are defined by deficits in social interactions, stereotypy, and delayed speech acquisition. In some cases, ASDs are accompanied by mental retardation and/or motor skill developmental delay. The neurological basis for autism may reflect enhanced local neural connectivity and impaired activity of prefrontal and temporal cortical regions serving integrative functions (Belmonte et al., 2004; Just et al., 2004). Neuroanatomical studies on autistic individuals have revealed cellular deficits in both limbic regions and the cerebellum (Pierce and Courchesne, 2001; Bauman and Kemper, 2005). Indeed, cerebellar dysfunction in animal models can induce autism-like behavioral deficits (Caston et al., 1998; Bobée et al., 2000).

ASDs can be triggered by environmental insult (Moore et al., 2000; Rasalam et al., 2005) or de novo genetic mutations (Jamain et al., 2003; Muhle et al., 2004; Durand et al., 2007; Sebat et al., 2007; Szatmari et al., 2007; Alarcón et al., 2008). A common feature of several implicated genetic loci is their specification of proteins intrinsic to synaptic architecture (Bourgeron, 2009), including presynaptic neurexin-1 (Szatmari et al., 2007), its postsynaptic adhesion counterparts neuroligin- 3 and -4 (Jamain et al., 2003), and the postsynaptic density (PSD) scaffolding pro-

Received March 6, 2010; revised April 17, 2010; accepted Aug. 28, 2010.

This work was supported by a component of the Specialized Neuroscience Research Program at Hunter College (Public Health Service Grant U54-NS40173) to M.G. and by the SENSOPAC grant from the European Union Cognitive Systems Initiative to E.D'A. We thank Laura Botta and Saranna Husband for assistance with PCR genotyping, and Jon Schoorlemmer for initial mapping of the IB2 genomic locus.

*J.G. and M.J.U. contributed equally to this work.

Correspondence should be addressed to Mitchell Goldfarb, Department of Biological Sciences, Room HN834, Hunter College, City University of New York, 695 Park Avenue, New York, NY 10065. E-mail: goldfarb@ genectr.hunter.cuny.edu.

DOI:10.1523/JNEUROSCI.1161-10.2010

Copyright $\odot 2010$ the authors $\quad$ 0270-6474/10/3014805-12\$15.00/0 tein SHANK3 (Durand et al., 2007). Mice engineered with corresponding mutations in neurexin or neuroligin genes show alterations in the balance of excitatory versus inhibitory synaptic transmission and, in some cases, ASD-like behavioral deficits (Tabuchi et al., 2007; Jamain et al., 2008; Etherton et al., 2009). Some mutations of these synaptic components also alter the balance of NMDA-type to AMPA-type EPSCs accompanying glutamatergic transmission (Kattenstroth et al., 2004; Khosravani et al., 2005). It is noteworthy that the NMDA receptor antagonist memantine has shown success in ameliorating core autistic symptoms (Chez et al., 2007).

The terminal region of chromosome 22q is a well documented ASD-associated locus. Deletions in Chr22q13.3 among individuals with ASD and the related Phelan-McDermid syndrome have defined the SHANK3 gene, located $1 \mathrm{Mb}$ from the chromosome terminus, as within the minimal deleted region (Wilson et al., 2003; Durand et al., 2007; Sebat et al., 2007; Delahaye et al., 2009). All but one of the $>50$ documented 22q13.3 deletions extend proximally from SHANK3 by at least $0.8 \mathrm{Mb}$ (Wilson et al., 2003; Sebat et al., 2007; Delahaye et al., 2009), thereby codeleting the MAPK8IP2 gene (also termed IB2 or JIP2) situated $70 \mathrm{kbp}$ from SHANK3. IB2 (for Islet Brain-2) is a protein expressed in neuronal and neuroendocrine cells (Negri et al., 2000), but with poorly understood function. IB2 interacts with many proteins, including IB1 (Yasuda et al., 1999), p38 MAP kinases, and their activating kinases (Schoorlemmer and Goldfarb, 2001, 2002; Buchsbaum et al., 2002; Robidoux et al., 2005), Rac exchange factors (Buchsbaum et al., 2002), lipoprotein receptors (Stockinger et al., 2000), amyloid precursor protein (Taru et al., 2002), fibroblast growth factor homologous factors (Schoorlemmer and Goldfarb, 2001), and kinesin (Verhey et al., 2001). IB2 has been speculated to act as a p38 MAPK signaling scaffold (Schoorlemmer and Goldfarb, 2001, 2002; Buchsbaum et al., 2002; Robidoux et al., 2005) and as an adaptor for kinesin-mediated protein trafficking 
along neurites (Verhey et al., 2001). However, in situ localization and in vivo biological functions of IB2 have not been described.

Here, we report analysis of IB2 protein subcellular distribution in the brain and deficits of mice lacking functional IB2 protein. IB2 is an integral constituent of PSDs in cerebellar and cerebral cortices. Mice lacking IB2 have morphologically normal PSDs with seemingly unaltered molecular composition (save IB2 deficiency), but display reduced AMPA and enhanced NMDA receptortype cerebellar glutamatergic transmission, altered Purkinje cell morphology, and motor and cognitive deficits. Behavioral deficits include reduced social interactions and impaired exploration of novel environments. Deletion of the IB2 gene may contribute to human ASD and PhelanMcDermid syndrome phenotypes in individuals bearing Chr22q13.3 deletions.

\section{Materials and Methods}

Generation and maintenance of IB2-1- mice

A $15.7 \mathrm{kbp}$ EcoRI genomic DNA fragment spanning the mouse IB2 gene was "floxed" (flanked by loxP) by inserting a cassette containing PGK-neo ${ }^{\mathrm{r}}$ and a loxP site (Meyers et al., 1998) at the BsrGI site in intron II and inserting loxP and EcoRI sites by QuikChange (Stratagene) site-directed mutagenesis within intron VIII to create the targeting vector (Fig. 1B). DNA from G418 ${ }^{\mathrm{r}}$ clones of mouse embryonic stem cells obtained by transformation with targeting vector were screened by Southern blotting with a hybridization probe $3^{\prime}$ to the targeting sequence, and EcoRIdigested DNA from candidate targeted clones were rescreened with the $5^{\prime}$ hybridization probe (Fig. $1 B$ ) to identify $I B 2+/$ flox cells (Fig. 1C). IB2flox was introduced into the mouse germline by stem cell injection into blastocysts, reimplantation, and breeding out chimeric mice onto 129Svev strain mice. One-cell-stage embryos harvested the morning after fertilization by IB2flox/flox fathers were injected with a CRE recombinase expression plasmid (O'Gorman et al., 1991) into the male pronucleus, reimplanted into pseudopregnant foster females, and progeny analyzed by Southern blotting with the $5^{\prime}$ probe to identify cases of CRE-mediated loxP excision generating the IB2 null allele (Fig. 1C). In subsequent breeding, genotyping was conducted by PCR, using four primers (Fig. $1 B$ ) to detect wild-type and null alleles (Fig. $1 D$ ). After establishing mice bearing the IB2 null allele, mutant mice were backcrossed onto the 129 Svev background for six generations. Subsequently, IB2-/- mice were routinely generated from $I B 2+/-$ mating pairs, as $I B 2-/-$ mice, although fertile, were poor breeders, possibly reflecting the social deficit associated with IB2 deletion (see Fig. 3).

Reverse transcription PCR analysis of brain gene expression Equal amounts of whole-brain RNA from $I B 2+/+$ and $I B 2-/-$ mice were reverse transcribed with oligo-dT primer and Mo-MLV reverse transcriptase, and resulting cDNA aliquots were subject to PCR assays using gene-specific primer pairs for ChkB, IB2, ARSA, and SHANK3.

\section{Antibodies used}

A bacterially expressed fragment of mouse IB2 (Schoorlemmer and Goldfarb, 2001) (residues 226-421) was used as immunogen for development and maintenance of monoclonal antibody N235/37 by the Uni- versity of California, Davis (UC Davis)/National Institutes of Health NeuroMab Facility in the Department of Neurobiology, Physiology, and Behavior at UC Davis (supported by Public Health Service Grant U24NS50606). N235/37 recognizes human, rat, and mouse IB2, but does not recognize IB1/JIP1. Other antibodies purchased for this study included mouse monoclonals anti-GluR2 (NeuroMab); NR1, NR2B, PSD95, rabbit polyclonal anti-NR2A, and guinea pig polyclonal anti-VGluT2 (Millipore); calbindin and synaptophysin (Sigma Chemical); secondary antibody peroxidase (Jackson ImmunoResearch Laboratories); and fluorescent conjugates (Invitrogen).

\section{Preparation of postsynaptic densities from cortical synaptosomes} and cerebellar glomeruli

Cerebral cortical homogenates were used to prepare synaptosomes at the $1 \mathrm{M} / 1.25 \mathrm{~m}$ sucrose density gradient interface, and cerebellar homogenates were used to prepare glomeruli at the $15 \% / 20 \%$ and $20 \% / 25 \%$ Ficoll density gradient interfaces, as described previously (Viennot et al., 1991; Phillips et al., 2001). Postsynaptic densities were isolated from these preparations by solubilization in $1 \%$ Triton X-100 at $\mathrm{pH} 6$, followed by pelleting at $40,000 \times \mathrm{g}$ for $30 \mathrm{~min}$.

\section{Immunoprecipitation and immunoblotting}

Immunoprecipitations were performed overnight on ice in $1 \%$ Triton X-100 buffer with $1 \mathrm{~mm}$ PMSF, $10 \mu \mathrm{g} / \mathrm{ml}$ aprotinin, and $10 \mu \mathrm{g} / \mathrm{ml}$ leupeptin, and captured onto protein-G agarose. For immunoblotting, samples were run on SDS polyacrylamide gels, electrotransferred to PVDF membrane, blocked with milk, and incubated with primary and secondary antibodies in saline buffer containing $0.1 \%$ Tween 20 and $2.5 \%$ calf serum, and proteins were detected by chemiluminescence. 


\section{Electrophysiological characterization of climbing fiber-Purkinje} cell synapses

Mice (postnatal day 30-40) were anesthetized and transcardially perfused with ice-cold low-chloride, glycerol-substituted ACSF $(250 \mathrm{~mm}$ glycerol, $2.5 \mathrm{~mm} \mathrm{KCl}, 1.2 \mathrm{~mm} \mathrm{MgCl}_{2}, 26 \mathrm{~mm} \mathrm{NaHCO}_{3}, 1.2 \mathrm{~mm} \mathrm{KH}_{2} \mathrm{PO}_{4}$, $2.4 \mathrm{mM} \mathrm{CaCl}_{2}$, and $11 \mathrm{~mm}$ glucose) bubbled with 95:5 $\mathrm{CO}_{2}: \mathrm{O}_{2}$ (Ye et al., 2006), and isolated cerebellar vermis was sliced sagittally at $300 \mu \mathrm{m}$ thickness in a vibratome. Slices were allowed to recover for at least $1 \mathrm{~h}$ at room temperature in ACSF ( $126 \mathrm{~mm} \mathrm{NaCl}, 3 \mathrm{~mm} \mathrm{KCl}, 1 \mathrm{mM} \mathrm{MgCl}_{2}, 26$ $\mathrm{mm} \mathrm{NaHCO}_{3}, 1.2 \mathrm{~mm} \mathrm{KH}_{2} \mathrm{PO}_{4}, 2.5 \mathrm{~mm} \mathrm{CaCl}_{2}$, and $10 \mathrm{~mm}$ glucose) bubbled with $95: 5 \mathrm{CO}_{2}: \mathrm{O}_{2}$ before transfer to unheated recording chamber containing magnesium-free ACSF. Borosilicate patch pipettes pulled on a Sutter P97 micropipette puller had electrical resistances of 2-3 M $\Omega$ when filled with solution consisting of $142 \mathrm{mM} \mathrm{CsCl}, 1 \mathrm{mM} \mathrm{MgCl}_{2}, 10 \mathrm{~mm}$ HEPES, 10 mm EGTA, 4 mm ATP, $0.4 \mathrm{~mm}$ GTP, and 2 mm QX-314, adjusted to $\mathrm{pH} 7.3$ with $\mathrm{CsOH}$. Purkinje cells visualized by infrared video microscopy were whole-cell patched, and recordings were made with a MultiClamp 700B amplifier (Molecular Devices) and electrical stimulator (Grass Technologies) coupled to Clampex10 software through a Digidata 1440 analog/digital converter (Molecular Devices). Immediately after establishment of whole-cell configuration and before substantial pipette buffer diffusion, voltage-clamp depolarization was used to induce large inward axonal sodium current ( $>1 \mathrm{nA}$ ), confirming the identity of the cells as Purkinje cells, as opposed to Bergmann glial cells. Thereafter, the slice was superfused with $\mathrm{GABA}_{\mathrm{A}}$ receptor antagonist bicuculline $(20 \mu \mathrm{M})$ and with NMDA receptor coagonist glycine $(25 \mu \mathrm{M})$ for $15 \mathrm{~min}$, and these components were present throughout recordings. First, cells were voltage clamped at $+40 \mathrm{mV}$; then, the climbing fiber within the granule cell layer below the patched Purkinje cell was stimulated at $0.03 \mathrm{~Hz}$, and evoked EPSCs were observed in all-or-nothing fashion as stimulus intensity was increased, confirming Purkinje cell innervation by a single climbing fiber (Urbanski et al., 2010). NMDA current is suppressed at $+40 \mathrm{mV}$ in these solutions, allowing solely for detection of outward non-NMDA currents (reversal potential $=+5$ $\mathrm{mV}$ ), as confirmed by subsequent suppression by superfusion with antagonist NBQX $(25 \mu \mathrm{M})$. Thereafter, the voltage clamp was shifted to -70 $\mathrm{mV}$ to reveal evoked inward NMDA current, which, if present, was subsequently confirmed by blocking with antagonist DL-AP5 $(50 \mu \mathrm{M})$. Under any treatment condition, evoked currents from five stimulations were averaged for subsequent analysis. Electrotonic properties of each patched cell were monitored throughout recording (supplemental Table 1 , available at www.jneurosci.org as supplemental material), and a cell was discarded from analysis if series resistance deviated by $>20 \%$ during recording.

\section{Electrophysiological characterization of mossy fiber-granule cell synapses}

Whole-cell patch-clamp recordings were performed from granule cells in acute cerebellar slices as reported previously (D’Angelo et al., 1999; Prestori et al., 2008). Briefly, isolated cerebellar vermis was rapidly chilled in ACSF solution and glued to the stage of a vibratome (Dosaka), and 250 $\mu \mathrm{m}$ slices were prepared. Slices were allowed to recover for at least $1 \mathrm{~h}$ at room temperature in ACSF solution bubbled with 95:5 $\mathrm{CO}_{2}: \mathrm{O}_{2}$ before transfer to a $32^{\circ} \mathrm{C}$ heated microscope stage. In some experiments, ACSF solution for recovery and recordings lacked $\mathrm{Mg}^{2+}$. GABA $\mathrm{A}$ receptor antagonist bicuculline (Enzo Life Sciences) at $10 \mu \mathrm{M}$ was added to perfusing ACSF solution before cell access. Borosilicate patch pipettes were filled with intracellular solution [ $81 \mathrm{~mm} \mathrm{Cs}_{2} \mathrm{SO}_{4}, 4 \mathrm{~mm} \mathrm{NaCl}, 2 \mathrm{~mm} \mathrm{MgSO}_{4}, 1$ mM QX-314, and $0.1 \mathrm{~mm}$ BAPTA (free acid), adjusted to $\mathrm{pH} 7.2$ with $\mathrm{CsOH}$ ] and had resistances of 5-7 $\mathrm{M} \Omega$ before seal formation. After achieving whole-cell access by gentle suction, cells were voltage clamped at $-70 \mathrm{mV}$ with a Multiclamp 700B amplifier (Molecular Devices) and input filtered at $10 \mathrm{kHz}$. Input data were sampled at $20 \mathrm{kHz}$ using pCLAMP 9 software in combination with a Digidata 1322A A/D converter (Molecular Devices). Mossy fibers were stimulated with a bipolar tungsten electrode via a stimulus insulation unit (Clark Instruments). EPSCs were elicited at $0.33 \mathrm{~Hz}$, and passive granule cell parameters were monitored intermittently by analysis of current transients induced by 10 $\mathrm{mV}$ hyperpolarizing voltage shifts (supplemental Table 1, available at www.jneurosci.org as supplemental material). Cells were held for $5 \mathrm{~min}$ at $-70 \mathrm{mV}$ and for $1 \mathrm{~min}$ at $+60 \mathrm{mV}$ to modify the NMDA/AMPA current ratio. This allowed for reliable estimates of both the AMPA (at $-70 \mathrm{mV}$ ) and NMDA (at $+60 \mathrm{mV}$ ) currents without using pharmacological blockers (D’Angelo et al., 1999; Rossi et al., 2002). EPSCs were averaged ( 100 traces at $-70 \mathrm{mV}$ and 20 traces at $+60 \mathrm{mV}$ ) and digitally filtered at $1.5 \mathrm{kHz}$ off-line. EPSC amplitude was measured at the peak at $-70 \mathrm{mV}$ and $15 \mathrm{~ms}$ after stimulation at $+60 \mathrm{mV}$ to measure the AMPA and NMDA currents, respectively. In some experiments, the NMDA/ AMPA current ratio was directly measured at $-70 \mathrm{mV}$ in $\mathrm{Mg}^{2+}$-free solution.

For quantal analyses, cells were clamped at $-70 \mathrm{mV}$ in bath solution containing $1.2 \mathrm{~mm} \mathrm{Mg}^{2+}$, and minimal EPSCs were obtained by finely tuning the stimulation intensity until responses jumped from zero to a definite level (Sola et al., 2004; Saviane and Silver, 2006). In control experiments, these minimal EPSCs at wild-type synapses had average amplitude and coefficient of variation (CV) similar to those in previous investigations (Rossi et al., 2002). At these synapses, besides the direct responses caused by glutamate acting at postsynaptic receptor sites, glutamate spillover causes slow nonzero responses called indirect responses. Stimulation failures were eliminated from analysis by identifying responses lacking both the direct and indirect response components (DiGregorio et al., 2002; Sola et al., 2004). The indirect response introduced an error into EPSC CV by causing nonzero failures; this error was eliminated by setting all indirect responses to zero (Sola et al., 2004). The effectiveness of this method was supported by the coincidence of the $\mathrm{CV}$ and failure methods in predicting release probability. Moreover, EPSC size and the estimated number of release sites coincided with those previously reported for unitary synapses in the rat, further supporting the effectiveness of minimal EPSC analysis.

The quantal parameters of release were obtained by using three statistical methods corresponding to Equations 1, 2, and 3 (see below) to improve the reliability of parameter estimation. These methods derive from binomial statistics and are only schematically described here, since they do not significantly differ from previous applications [for a comprehensive treatment, see McLachlan (1978), Clements and Silver (2000), Clements (2003), Sola et al. (2004), and Mapelli et al. (2009)]. The quantal theory states that the mean number of quanta released at each impulse ( $m$, mean quantum content) depends on the number of releasing sites $(n)$ and on the probability $(p)$ that each quantum ( $q$, quantum size) is released, so that EPSC variance $\left(S^{2}=\mathrm{SD}^{2}\right)$ and mean amplitude $(M=m q)$ are related through a parabolic function and EPSC variation depends on the number of released quanta. The relationship between EPSC $S^{2}$ and $M$, previously constructed by using different $\mathrm{Ca}^{2+}$ concentrations in the extracellular solution (Sola et al., 2004), was analyzed using a binomial model under the assumption of homogeneous release probability [this was supported by the substantial symmetry of the data distribution (see Clements and Silver, 2000)]:

$$
S^{2}=q_{p} M\left(1+\mathrm{cv}_{1}^{2}\right)-\frac{M^{2}}{n}
$$

The model can also be applied without a knowledge of the whole variance/mean distribution (McLachlan, 1978), since the parameters $p$ and $n$ can be calculated from the mean amplitude and coefficient of variation of $\operatorname{EPSCs}\left(M=m q_{p}\right.$ and CV $=S / M$, where $S$ is EPSC SD). In this model $m=$ $n p, \mathrm{SD}^{2}=n p(1-p)$, and the probability $p$ is as follows:

$$
p=1-\frac{M \cdot \mathrm{CV}^{2}}{q_{p}\left(1+\mathrm{cv}_{1}^{2}\right)} .
$$

An estimate of $p$ could also be obtained from the failure rate $\left(\mathrm{FR}=N_{0} / N\right.$; $N_{0}$ is the number of failures out of $N$ responses), which does not explicitly depend on previous determinations of quantum properties except that the number of releasing sites needs to be calculated beforehand with Equation 1 or Equation 2:

$$
p=1-\left(N_{0} / N\right)^{1 / n} .
$$


Although the three methods have different dependencies on experimental measurements and different intrinsic estimation errors (McLachlan, 1978 ), they yielded very similar parameter values, supporting the reliability of $p$ estimates.

\section{Morphological analysis of cerebellar Purkinje cells and their climbing fiber innervation}

Vibratome cerebellar slices, performed as described above for electrophysiology, were used to obtain whole-cell patch access to Purkinje cells in the involution between lobules 4 and 5 using pipettes filled with intracellular solution (as above) containing $1 \mathrm{~mm}$ biocytin-Oregon Green. Cell processes were filled by diffusion for $15 \mathrm{~min}$, the pipette was pulled away slowly, and successful resealing was judged by dye retention for at least $15 \mathrm{~min}$. Slices were then fixed with $4 \%$ paraformaldehyde, stained with TOPRO iodide (Invitrogen), and mounted with Vectashield reagent for confocal fluorescence microscopy (Leica Instruments). Imaris software was used to render three-dimensional neuron reconstructions from optical stacks of confocal images spaced $2 \mu \mathrm{m}$ apart and to measure dendritic parameters. To assess climbing fiber innervation, we anesthetized and cardiac perfused the mice with buffered saline containing $4 \%$ paraformaldehyde before isolating brains and collecting $20 \mu \mathrm{m}$ cryosections on slides. Sections were briefly postfixed, permeabilized in PB (0.1 M sodium phosphate $\mathrm{pH} 7.2)$ containing $0.5 \%$ Triton $\mathrm{X}-100$, blocked in PBT $(\mathrm{PB}+0.25 \%$ Triton $)+10 \%$ calf serum, and incubated overnight with primary antibodies against calbindin and VGluT2 in PBT $+2.5 \%$ BSA (bovine serum albumin). Sections were subsequently washed in PBT, incubated with fluorescent secondary antibody conjugates, rewashed, and stained with TOPRO-iodide before mounting with VectaShield. Fluorescent images were captured by confocal microscopy (Leica Instruments), and images through the $z$-axis were summated to visualize Purkinje cell dendritic arbors and their climbing fiber varicosities.

\section{Cerebellar histology}

Midline fixed brain sections, prepared as described above for immunofluorescence, were Nissl stained and used for measurements of granule layer and molecular layer thicknesses along the straight involutions of lobules 3 and 4 .

\section{Electron microscopy}

Brains were fixed with $1 \%$ paraformaldehyde- $2 \%$ glutaraldehyde by transcardial perfusion, sliced into $0.75 \mathrm{~mm}$ segments, and postfixed with $4 \%$ osmium tetroxide in phosphate buffer for $3 \mathrm{~h}$ at $4^{\circ} \mathrm{C}$. After graded ethanol washes up to $70 \% \mathrm{v} / \mathrm{v}$, tissue was stained with $2 \%$ uranyl acetate in $70 \%$ ethanol for $4 \mathrm{~h}$ at $4^{\circ} \mathrm{C}$, then further dehydrated at room temperature to pure ethanol. Resin embedding was performed by a sequential perfusion with propylene oxide, a 1:1 mixture of propylene oxide:epoxy monomer overnight, and pure epoxy monomer for $6 \mathrm{~h}$ with agitation. Trimmed blocks were hardened $48 \mathrm{~h}$ at $60^{\circ} \mathrm{C}$, and ultrathin slices were collected onto mesh grids. Following further stainings with lead nitrate and uranyl acetate, structures were imaged using a Hitachi H7500 electron microscope.

\section{Assays of mouse behavior}

Rotarod. Mice were tested three times per day for $4 \mathrm{~d}$ on an accelerating rotarod (IITC Instruments). For each trial, a mouse was started on the rotarod rotating at $1 \mathrm{rpm}$ and accelerated at a rate of $4.7 \mathrm{rpm} / \mathrm{min}$ until falloff. Time to falloff for the first trial of each day was used for analysis.

Grip strength. Mice were tested three times in a day at postnatal days 21,28 , and 35 . Animals were allowed to forepaw grasp a horizontal sensor bar of a Grip Strength monitor (Columbus Instruments), and pulled by the tail until breakaway. The average force recorded for the three trials was accepted for analysis.

Social interaction. Pairs of female or male mice that had never interacted before were placed together in a new $15 \times 19$ inch cage and allowed to freely interact for $10 \mathrm{~min}$ while being video recorded. Social interaction was judged as time mice spent in physical contact or in close pursuit accompanied by sniffing. Pairs were scored for total interaction time and length of interaction for each encounter.
Olfaction. As a qualitative test for an intact olfactory system, mice were tested for their ability to approach and sniff at the opening of an opaque horizontal tube containing cheese hidden at its base in preference to another tube without cheese.

Vision. As a qualitative test for an intact visual system, mice were picked up by the tail and slowly lowered to a wire cage lid. Vision was reflected in an animal's extending its forepaws and attempting to grip the lid just before contact with the surface.

Locomotion. Individual mice were placed in a new $9.5 \times 18$ inch cage and allowed to freely explore for $10 \mathrm{~min}$ while being video recorded, with locomotion scored as time spent engaged in quadrupedal movement (walking). In one such experiment, assays were first performed in the animals' home room, and mice were retested on subsequent days in a novel room (nearby procedure room). In other experiments, the assays were performed directly in the novel room environment. In a later experiment, movement was quantitated with the aid of laser beam break detection system after oral administration of memantine ( $25 \mathrm{mg} / \mathrm{kg} / \mathrm{d}$ for $14 \mathrm{~d})$.

Elevated T-maze. The T-maze was elevated 16 inches above a table and consisted of three arms, 26 inches long and 2 inches wide, with the base arm bearing high side panels (enclosed arm) and the two side arms exposed. Mice were allowed to enter the enclosed arm through a distal access door and video recorded for $5 \mathrm{~min}$, monitoring for time spent in exposed arms, crosses between enclosed and exposed arms, and pauses with head protrusions (scannings) from enclosed arm out into exposed intersection. Behavior is normally governed by fear of entering and remaining in the exposed arms.

\section{Statistics}

For all analyses of wild-type and mutant populations (behavior, electrophysiology, neuronal morphology, and histology assays), data were expressed as mean $\pm S D$, and statistical significance for differences between genotypes were determined by Student's $t$ test (two-tailed).

\section{Results}

\section{Generation of $I B 2-/-$ mice}

The IB2 gene resides on mouse chromosome 15 within $35 \mathrm{kbp}$ of SHANK3 (Fig. 1A), similar to the linkage seen in human chr22qter. The IB2 locus was targeted in mouse embryonic stem cells to generate a loxP-flanked (floxed) IB2 allele that was introduced into the mouse germ line by blastocyst injection (Fig. $1 B, C)$. Initial efforts to use these floxed-IB2 mice for CRE recombinase-mediated conditional disruption of the IB2 gene gave unsatisfactory efficiencies of loxP excision in brain tissue (data not shown). The floxed-IB2 mice were subsequently used to generate a constitutional disruption of the floxed allele [herein referred to as $I B 2-$ allele (Fig. $1 B$ )] by CRE plasmid injection into single-cell embryos. Resulting $I B 2+/-$ mice (Fig. $1 C$ ) could be intercrossed to generate viable $I B 2-/-$ progeny (Fig. $1 D$ ). Subsequent analyses of the IB2-/- phenotype were performed after two backcross generations onto the 129/Svev strain (herein called mixed background) or after six backcross generations (termed 129/Svev background).

Reverse transcription PCRs (RT-PCRs) were performed to ensure that normal brain expression of neighboring genes $C h k B$, $A R S A$, and SHANK3 was not silenced in IB2-/- mice. Indeed, IB2 targeting did not disrupt expression of the neighboring genes (Fig. $1 E)$.

\section{IB2 protein is widely distributed in brain and is enriched at postsynaptic densities}

The distribution of IB2 protein in brain tissue and cultured neurons was examined using monoclonal N135/37 antibody generated against a mouse IB2 protein fragment lacking homology to IB1/JIP1/MAPK8IP1 (see Materials and Methods). IB2 protein is broadly distributed throughout the brain, and on immunoblots migrates with apparent molecular weight of $\sim 150,000$ in lysates 

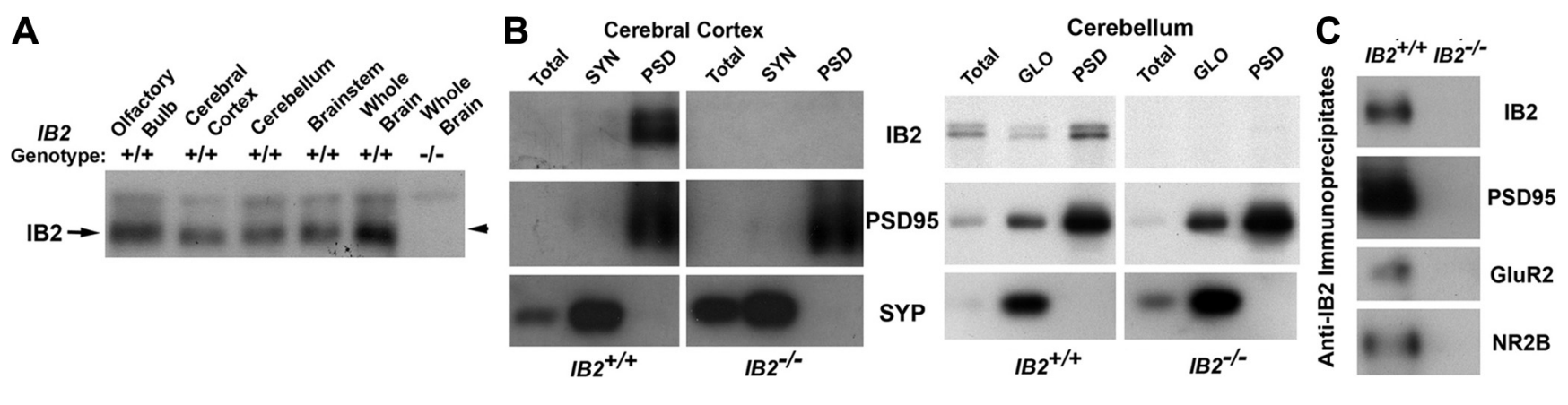

Figure 2. Broad distribution and synaptic enrichment of IB2 protein. A, Immunoblot detection of IB2 in mouse brain. Triton X-100-soluble extracts from whole brain or brain regions of $/ B 2+/+$ and IB2 - / - mice were electrophoresed and immunoblotted, probing with monoclonal antibody to IB2. IB2 protein running with apparent molecular weight of 150,000 is expressed in all examined regions. $B, I B 2$ enrichment in postsynaptic densities. Homogenates from IB2 $+/+$ and IB2 - / - cerebral cortex (left) or cerebellum (right) were used to prepare synaptosomes (SYN) or glomeruli (GLO), respectively, each of which was then used to extract PSDs. Equal amounts of protein from all fractions were analyzed by immunoblotting for IB2, PSD-95, and synaptophysin (SYP). PSDs from IB2+/+ cortical synaptosomes and cerebellar glomeruli are enriched for IB2 and PSD-95. C, Coimmunoprecipitation of IB2 and other PSD proteins. Whole-brain Triton X-100-soluble extracts from IB2 + / + and IB2 - / - mice were immunoprecipitated with anti-IB2 and then immunoblotted with antibodies to IB2, PSD-95, AMPAR subunit GluR2, or NMDAR subunit NR2B. All of these PSD proteins coimmunoprecipitated with IB2 from the IB2+/+ extract.
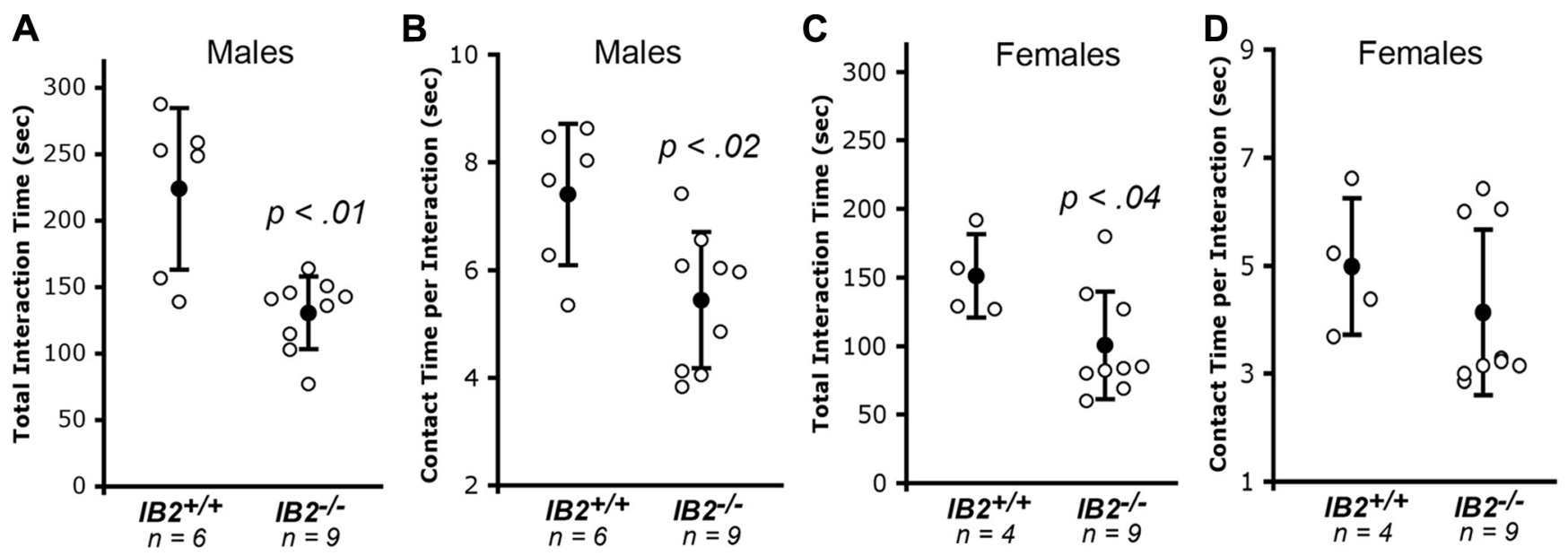

Figure 3. $I B 2-/-$ mice are less socially interactive. Pairs of $I B 2+/+$ or $I B 2-/-$ male $(\boldsymbol{A}, \boldsymbol{B})$ or female $(\boldsymbol{C}, \boldsymbol{D})$ mice (mixed background) were placed in a large new cage and monitored over 10 min for social interaction, judged as close pursuit or physical contact with sniffing. IB2-/- pairs engaged in significantly less total interaction time ( $\boldsymbol{A}$, $\boldsymbol{C}$ ), which for males was attributed to shorter duration of interaction per contact $(\boldsymbol{B})$. Behaviors are illustrated in supplemental Movie 1 (available at www.jneurosci.org as supplemental material).

from wild-type mice, but not from IB2-/- mice (Fig. 2A). IB2 is more abundant in a cerebral cortical synaptosome preparation, and is strongly enriched in the derivative PSD fraction (Fig. $2 B$ ). Cerebellar glomerular PSDs are also enriched for IB2 (Fig. 2B). As an integral component of the large PSD complex, several other PSD components, including AMPA receptor subunit GluR2, NMDA receptor subunit NR2B, and the scaffold PSD-95, coimmunoprecipitate with IB2 from wild-type whole-brain lysate, but not from IB2-/- lysate (Fig. 2C).

\section{Social interaction deficit in $I B 2-/-$ mice}

We conducted a broad behavioral survey of IB2 $-/-$ mice relative to wild-type controls, as warranted by the wide distribution of IB2 protein throughout the brain. These assays revealed cognitive and motor deficits in $I B 2-/-$ mice.

IB2 - / - mice were assayed for potential deficits in social interactions. Pairs of mice (35-45 d old) never previously housed together were placed in a large new cage and allowed to interact with each other for $10 \mathrm{~min}$; their time engaged in social interaction, judged by contact accompanied by sniffing, was measured from video recordings. Social interaction times between pairs of mutant male mice (131 $\pm 27 \mathrm{~s}, n=9$ ) were significantly less than between pairs of wild-type males (224 $\pm 61 \mathrm{~s}, n=6, P<0.01)$
(Fig. 3A; supplemental Movie 1, available at www.jneurosci.org as supplemental material). Reduced overall interaction of mutant male pairs was reflected in part by a shorter interaction time per encounter (mutant $5.4 \pm 1.3 \mathrm{~s}$ vs wild-type $7.4 \pm 1.3 \mathrm{~s}, P<0.01$ ) (Fig. 3B; supplemental Movie 1, available at www.jneurosci.org as supplemental material). Mutant female pairs also interacted significantly less (101 $\pm 39 \mathrm{~s}, n=9)$ than did wild-type females $(151 \pm 30 \mathrm{~s}, n=4, P<0.04)$ (Fig. 3C). When not interacting with each other, all mice were active through the entire testing period, engaging in walking, rearing, burrowing, and grooming behaviors (supplemental Movie 1, available at www.jneurosci.org as supplemental material). Impaired social interaction may account for the poor breeding habits of IB2- - - mice (see Materials and Methods). The social interaction deficit of $I B 2-/-$ mice was not secondary to a serious visual or olfactory impairment. In separate simple tests of vision and olfaction (see Materials and Methods), screened mutants could see a surface above which they were suspended and could navigate by smell to the open end of an opaque tube containing hidden cheese.

\section{Exploratory deficit in IB2-/- mice}

Additional behavioral assays were aimed at testing environmental exploration. Most striking were the results of locomotor tests 

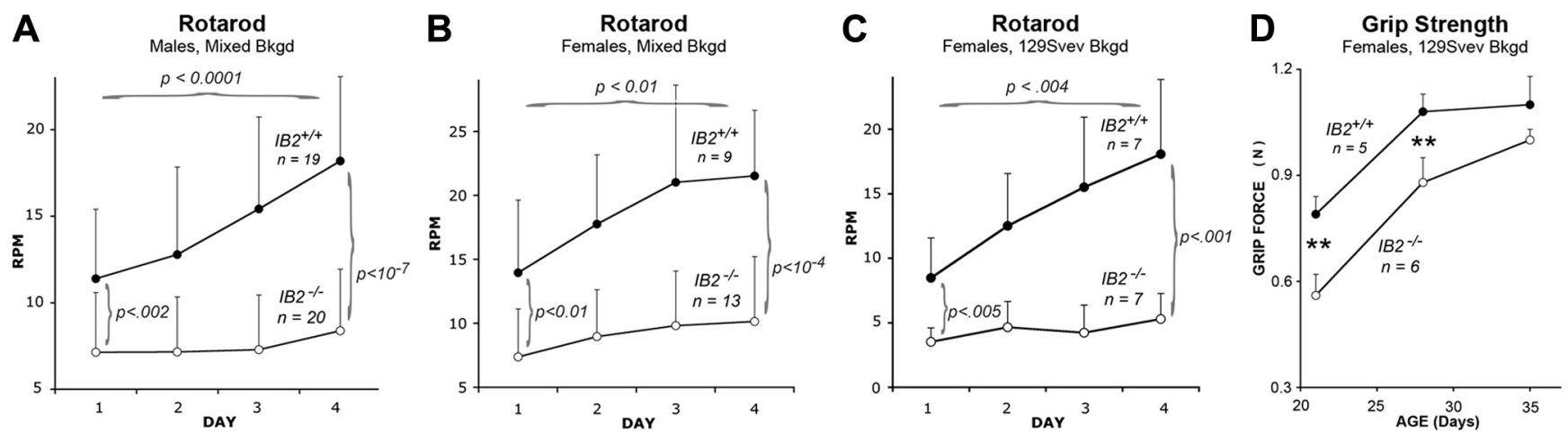

Figure 4. $I B 2-/-$ mice show impaired motor performance and learning. $I B 2+/+$ and $I B 2-/-$ mice were tested for baseline motor performance and learning on an accelerating rotarod for 4 consecutive days and scored for rod revolution speed at time of fall-off. Data are shown for males of mixed background $(\boldsymbol{A})$, females of mixed background $(\boldsymbol{B})$, and females of $129 /$ SvEv background (C). For all cohorts, IB2 +/+ mice performed better at initial testing than IB2 - / - mice, and only IB2 $+/+$ mice improved significantly over the $4 \mathrm{~d}$ testing period. $D$, Grip strength of $I B 2+/+$ and IB2 - / - female mice on 129/SvEv background. Forepaw grip strength while resisting pull-off from sensor bar was monitored between 3 and 5 weeks of age. IB2 - / - animals showed mildly delayed strength acquisition, but did not differ significantly from IB2 $+/+$ mice by week 5 .

on individual mice transferred to a large new cage. Wild-type and mutant female mice ( $n=8$ each) were equally active when the new cage test was performed in the home room (supplemental Table 1, supplemental Movie 2, available at www.jneurosci.org as supplemental material). On subsequent days, when the same animals were retested in a nearby procedure room, activity of mutants fell precipitously in comparison to wild-type animals $(P<$ 0.005 on days $4-6)$. When separate cohorts of mice were first tested in a novel procedure room, the mutants were immediately less active (supplemental Table 1, available at www.jneurosci.org as supplemental material). The animals would perform pivots, head and forepaw protrusions, and occasional grooming, but would not walk quadrupedally in the cage (supplemental Movie 3, available at www.jneurosci.org as supplemental material). These experiments show that $I B 2-/-$ mice are not intrinsically deficient in locomotor activity, but become nonresponsive when moved to a sufficiently novel environment. In several other assays with a locomotor component, such as escape from light to dark environment and novel object exploration, many mutant animals would not walk (data not shown), likely reflecting a similar locomotor shutdown in these novel environments.

To test whether mutant mouse locomotor shutdown in novel environments reflects a heightened fear response, $I B 2-/-$ mice were also tested for fear response in an elevated T-maze apparatus, where fear is assayed as reluctance to proceed from the enclosed arm into the open arms of the maze. Surprisingly, on the first day of testing, IB2- - mice actually expressed reduced fear than did $I B 2+/+$ mice, spending more time in the open arms and making fewer pauses at the exit from the enclosed arm (supplemental Fig. $1 A, B$, available at www.jneurosci.org as supplemental material). By the third day of testing, mutant and wild-type mice avoided the maze's open arms to similar extents (supplemental Fig. 1 $A$, available at www.jneurosci.org as supplemental material).

\section{Motor performance and learning deficit in $I B 2-/-$ mice}

To test baseline motor performance and learning in $I B 2-/-$ mice, adult animals (35-45 d old) were assayed over several days on an accelerating rotarod. Animals were scored for rod revolution speed (in rotations per minute) at fall-off, with males and females on either the mixed or 129/Svev background scored separately (Fig. $4 A-C$ ). For all cohorts, IB2-/- mice performed significantly poorer on the first day than did wild-type mice $(P<$ 0.01 or better for all cohort comparisons). Furthermore, wild- type mice improved over $4 \mathrm{~d}$ of trials $(P<0.01$ or better for all cohort comparisons), while performance of $I B 2-/-$ animals did not improve significantly with practice. Poorer rotarod performance by mutants was not readily attributable to impaired balance or strength. Mutant mice could maintain themselves on a narrow $(7.5 \mathrm{~mm}$ ) ledge for an entire $1 \mathrm{~min}$ testing period, indicative of good balance (data not shown). Additionally, by 4 weeks of age, all IB2-/ - mice could support themselves on an inverted mouse cage lid for an entire 1 min testing period (data not shown), although younger mutant animals had greater difficulty with this assay. Grip strength was more quantitatively measured as resistance to pull-off from a monitoring bar. Strength for both wild-type and IB2-/- animals increased with maturity, and a modest juvenile strength deficiency in IB2-/- mice was no longer significant by 5 weeks of age (Fig. 4D). Overall, we conclude that the severely impaired baseline performance and lack of improvement on rotarod by $I B 2-/-$ mice primarily represent poor sensorimotor processing reflecting cerebellar functional deficits in the mutants.

\section{IB2-/- glutamatergic synapses have normal molecular composition and ultrastructure}

The rotarod performance deficits of $I B 2-/-$ mice (Fig. 4) pointed toward impaired cerebellar function in these animals. In light of these findings, ultrastructure of cerebellar glutamatergic synapses was analyzed by electron microscopy. The architecture of glomeruli containing mossy fiber-granule cell synapses and of molecular layer parallel fiber-Purkinje cell synapses appeared normal in $I B 2-/-$ cerebellum (Fig. $5 A-D$ ), featuring normal synaptic clefts and postsynaptic densities, and abundant presynaptic vesicles. To determine whether loss of IB2 alters the postsynaptic molecular composition of glutamatergic synapses, additional immunoblots were performed on postsynaptic density preparations from wild-type and IB2-/- cerebral cortical synaptosomes and from cerebellar glomeruli. These experiments showed that levels of AMPA-type receptor subunit GluR2 and NMDA-type receptor subunits NR1, NR2A, and NR2B are not significantly affected in $I B 2-/-$ versus wild-type preparations (Fig. $5 E, F)$.

Reduced AMPA and elevated NMDA neurotransmission at IB2-/- cerebellar mossy fiber to granule cell synapses

Despite normal synaptic ultrastructure and composition, glutamatergic transmission in cerebellum was significantly altered by 

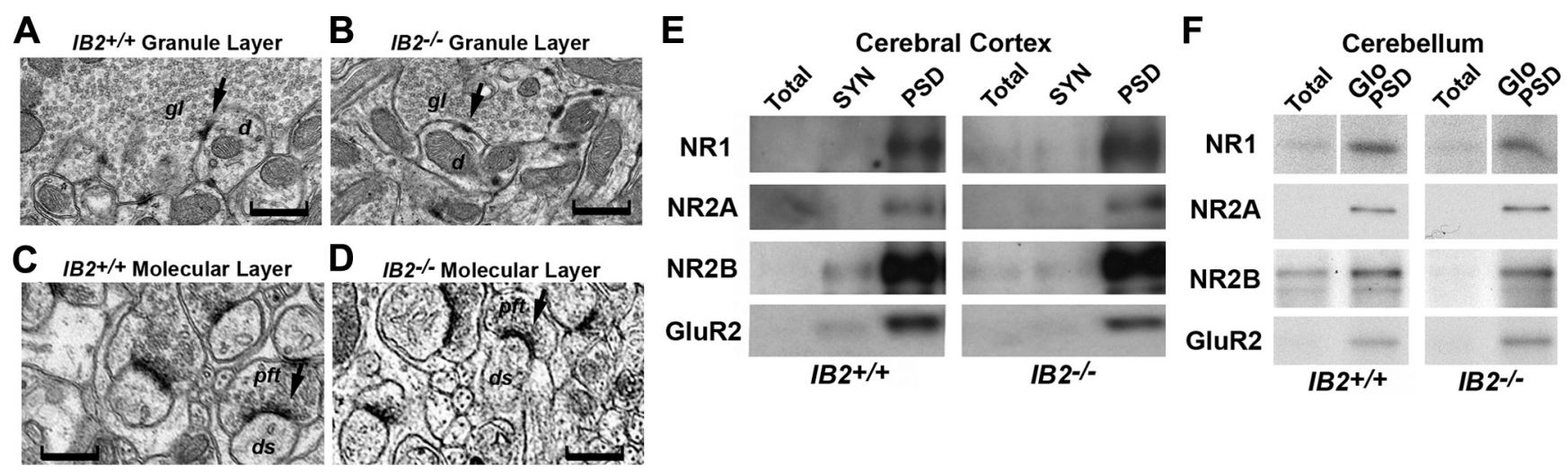

Figure 5. Ultrastructurally and molecularly normal synapses in $/ B 2-/-$ mice. $A-D$, Electron micrographs of synapses in cerebellar granule layers $(\boldsymbol{A}, \boldsymbol{B})$ and molecular layers $(\boldsymbol{C}, \boldsymbol{D})$ of $/ B 2+/+$ $(\boldsymbol{A}, \boldsymbol{C})$ and $I B 2-/-(\boldsymbol{B}, \boldsymbol{D})$ animals. Synapses (arrows) in IB2 - / - cerebellum appear normal. gl, Glomerulus; $d$, dendritic spine; pft, parallel fiber terminal; ds, Purkinje dendritic spine. Scale bar, 500 nm. $\boldsymbol{E}, \boldsymbol{F}$, Immunoblot detection of glutamate receptor subunit enrichment in cerebral cortical synaptosome-derived $(\boldsymbol{E})$ and cerebellar glomerulus-derived $(\boldsymbol{F})$ PSD preparations. Receptor abundances in IB2 - / - PSDs are normal.

IB2 deletion. Synaptic transmission at the mossy fiber-granule cell relay was investigated through whole-cell patch-clamp recordings obtained from granule cells in P18-P22 mouse acute cerebellar slices. The granule cells of IB2-/- and wild-type mice showed similar membrane capacitances and resistances (supplemental Table 2, available at www.jneurosci.org as supplemental material). EPSCs were recorded in the presence of extracellular $1.2 \mathrm{mM} \mathrm{Mg}^{2+}$ at both $-70 \mathrm{mV}$ and $+60 \mathrm{mV}$ as well as in $\mathrm{Mg}^{2+}$ free solution at $-70 \mathrm{mV}$. Thus, the NMDA current could be measured either at $+60 \mathrm{mV}$ after removing the voltagedependent $\mathrm{Mg}^{2+}$ block by depolarization or at $-70 \mathrm{mV}$ after removing extracellular $\mathrm{Mg}^{2+}$. The combination of these two measurements allowed for a reliable assessment of the differential contribution of the AMPA and NMDA EPSC components (D’Angelo et al., 1995; D'Angelo et al., 1999; Cathala et al., 2003) and for comparison of the NMDA/AMPA ratio in wild-type and IB2-/- mice (Fig. 6A,B; supplemental Table 2, available at www.jneurosci.org as supplemental material). AMPA currents were reduced at IB2-/ - compared to wild-type synapses $[-21.1 \pm 2.2 \mathrm{pA}(n=8)$ vs $-31.6 \pm 3.8 \mathrm{pA}(n=5) ; P<0.05]$, while NMDA currents were enhanced at mutant synapses $[30.3 \pm 4.6 \mathrm{pA}(n=8)$ vs $13.3 \pm 2.6 \mathrm{pA}(n=5) ; P<0.005]$, resulting in a 3.3 -fold increase in the NMDA/AMPA ratio at IB2- / - mossy fiber-granule cell synapses $[1.5 \pm 0.2(n=8)$ vs $0.46 \pm 0.04(n=5) ; P<0.005$ ] (Fig. $6 A, B$; supplemental Table 2, available at www.jneurosci.org as supplemental material). To assess whether elevated NMDA currents at synapses in cerebellum or other brain centers could account for some behavioral deficits in IB2-/- mice, we reassayed for locomotion in a novel environment following chronic administration of the general NMDA receptor antagonist memantine. Indeed, NMDA receptor antagonism largely rescued the locomotion deficit experienced by IB2-/- mice (supplemental Table 1, available at www.jneurosci. org as supplemental material).

We performed additional experiments using minimal stimulation intensity to describe neurotransmission quantal properties at putative single mossy fiber-granule cell synapses in IB2-/and wild-type mice (Fig. $6 C-E$; supplemental Table 2, available at www.jneurosci.org as supplemental material). IB2-/- mice showed smaller minimal EPSC amplitude $[-15.8 \pm 1.8 \mathrm{pA}(n=$ $8)$ vs $-24.8 \pm 1.2 \mathrm{pA}(n=8) ; P<0.005]$ and greater $\mathrm{CV}[0.58 \pm$ $0.06(n=8)$ vs $0.36 \pm 0.04(n=8) ; P<0.01]$ than wild-type mice (Fig. 6C,E; supplemental Table 2, available at www.jneurosci.org as supplemental material). Evoked EPSC reduction was paral- leled by smaller miniature EPSC amplitudes at mutant than at wild-type synapses $[-8.7 \pm 0.5 \mathrm{pA}$ vs $-10.9 \pm 0.8 \mathrm{pA} ; P<0.05]$. Moreover, IB2 $-/-$ mice showed a higher FR than wild-type mice $[19.3 \pm 3.6 \%(n=8)$ vs $5.3 \pm 1.7 \%(n=8) ; P<0.01]$ (Fig. $6 C, E$; supplemental Table 2, available at www.jneurosci.org as supplemental material). CV and FR values were used to calculate quantal release probability $(p)$, which was found to be significantly smaller in IB2-/ - than in wild-type mice. The values of $p$ calculated from CV (see Materials and Methods, Eq. 2) were $0.46 \pm$ $0.08(n=8)$ in IB2- - and $0.69 \pm 0.06(n=8)$ in wild-type mice $(P<0.05)$, with the number of release sites not significantly changed $(n=4.7 \pm 0.8$ vs $3.7 \pm 0.6)$. The values of $p$ calculated from FR (see Materials and Methods, Eq. 3) were $0.40 \pm 0.07$ $(n=8)$ in $I B 2-/-$ and $0.65 \pm 0.04(n=8)$ in wild-type mice $(P<0.05)$ (supplemental Table 2, available at www.jneurosci.org as supplemental material). These data suggest that the overall reduced AMPA currents at this relay in $I B 2-/-$ mice are predominantly the consequence of reduced presynaptic glutamate release probability $(33 \%)$, and also of reduced quantum size (20\%). IB2-/- synapses on average also displayed significantly weaker paired-pulse depression than their wild-type counterparts (Fig. 6D,E; supplemental Table 2, available at www. jneurosci.org as supplemental material), also consistent with a presynaptic deficit in neurotransmission. That mutant synapses, in fact, show significantly elevated NMDA currents thereby suggests that $I B 2-/-$ granule cells have a substantially elevated postsynaptic NMDA conductance.

\section{Reduced and delayed AMPA/kainate neurotransmission at} IB2-/- cerebellar climbing fiber to Purkinje cell synapses Transmission at climbing fiber-Purkinje cell synapses was investigated through whole-cell patch-clamp recordings obtained from Purkinje cells in P30-P40 mouse acute cerebellar slices. Patched cells were clamped at $+40 \mathrm{mV}$, and their underlying climbing fibers were stimulated at $0.03 \mathrm{~Hz}$ to evoke EPSCs. All wild-type cells $(n=11)$ displayed characteristic large all-ornothing AMPA/kainate NBQX-sensitive outward currents $(17.0 \pm 5.6 \mathrm{pA} / \mathrm{pF})$ with rapid rise time $(2.46 \pm 0.48 \mathrm{~ms})$ and decay time $\left(\tau_{\text {fast }}=5.75 \pm 1.69 \mathrm{~ms}\right)$ (Fig. $7 A, D$; supplemental Table 3, available at www.jneurosci.org as supplemental material). IB2-/- Purkinje cells $(n=17)$ displayed far more variable responsiveness, which reflected two distinct classes of neurotransmission (supplemental Table 3, available at www.jneurosci. org as supplemental material). For one subset of mutant cells 
(53\%, 9 of 17 cells), AMPA/kainate EPSCs had properties similar to wild-type cells, including peak current density (19.0 \pm $12.3 \mathrm{pA} / \mathrm{pF})$, rise time $(2.17 \pm 0.55 \mathrm{~ms})$, and decay time $\left(\tau_{\text {fast }}=6.02 \pm 2.52 \mathrm{~ms}\right)$ (Fig. $7 B, D$; supplemental Table 3 , available at www.jneurosci.org as supplemental material). However, the second subset of IB2-/- Purkinje cells $(47 \%, 8$ of 17 cells) had AMPA/kainate EPSCs with only about $1 / 10$ the peak current density $(1.8 \pm$ $0.7 \mathrm{pA} / \mathrm{pF} ; P<10^{-5}$ vs wild type) and far greater rise time $\left(16.8 \pm 4.8 \mathrm{~ms} ; P<10^{-4}\right.$ vs wild type) and decay time (20.5 \pm 5.6 ms; $P<10^{-4}$ vs wild-type) (Fig. $7 C, D$; supplemental Table 3, available at www. jneurosci.org as supplemental material).

Recently, climbing fiber stimulation has been shown to evoke NMDA currents in Purkinje cells of C57BL/6 mice (Piochon et al., 2007). Therefore, we assayed for NMDA currents in wild-type and IB2-/Purkinje cells, which are on a $129 /$ Svev background. On this background, AP5sensitive NMDA currents were detected only infrequently in both wild-type (2 of $11)$ and $I B 2-/-$ (2 of 17) Purkinje cells (supplemental Table 3, available at www. jneurosci.org as supplemental material). The infrequency of NMDA transmission at climbing fiber-Purkinje cell synapses thereby precluded evaluation of a potential effect of IB2 deletion on NMDA transmission at this relay.

\section{Altered Purkinje cell morphology in IB2-/ - cerebella}

The motor and cerebellar synaptic transmission deficits in IB2-/- mice prompted additional analysis of cerebellar morphology, focusing on dendritic arborization of Purkinje cells and climbing fiber innervation. Arbors and spines of individual Purkinje cells from 3- to 4-week-old mice were visualized by filling live cells in acute slices with biocytin-Oregon Green, followed by fixation and confocal microscopy of serial optical sections. Many parameters of IB2-/- Purkinje cell arbors did not differ significantly from wild type, including number of branch points, average branch length, number of dendritic termini, and dendritic spine density (Fig. 8A, B; supplemental Table 4, available at www.jneurosci.org as supplemental material). However, total dendritic intracellular volumes of $I B 2-/-$ Purkinje cells were $\sim 45 \%$ less than those of wild-type cells, indicating that mutant cell dendrites are substantially thinner (supplemental Table 4, available at www.jneurosci. org as supplemental material). Additionally, the overall heights of $I B 2-/$ - dendritic arbors were $\sim 25 \%$ shorter than those of wildtype arbors (Fig. $8 A, B$; supplemental Table 4 , available at www. jneurosci.org as supplemental material). As shown in Figure $8 B$, this shorter IB2-/- Purkinje cell arbor nonetheless spanned
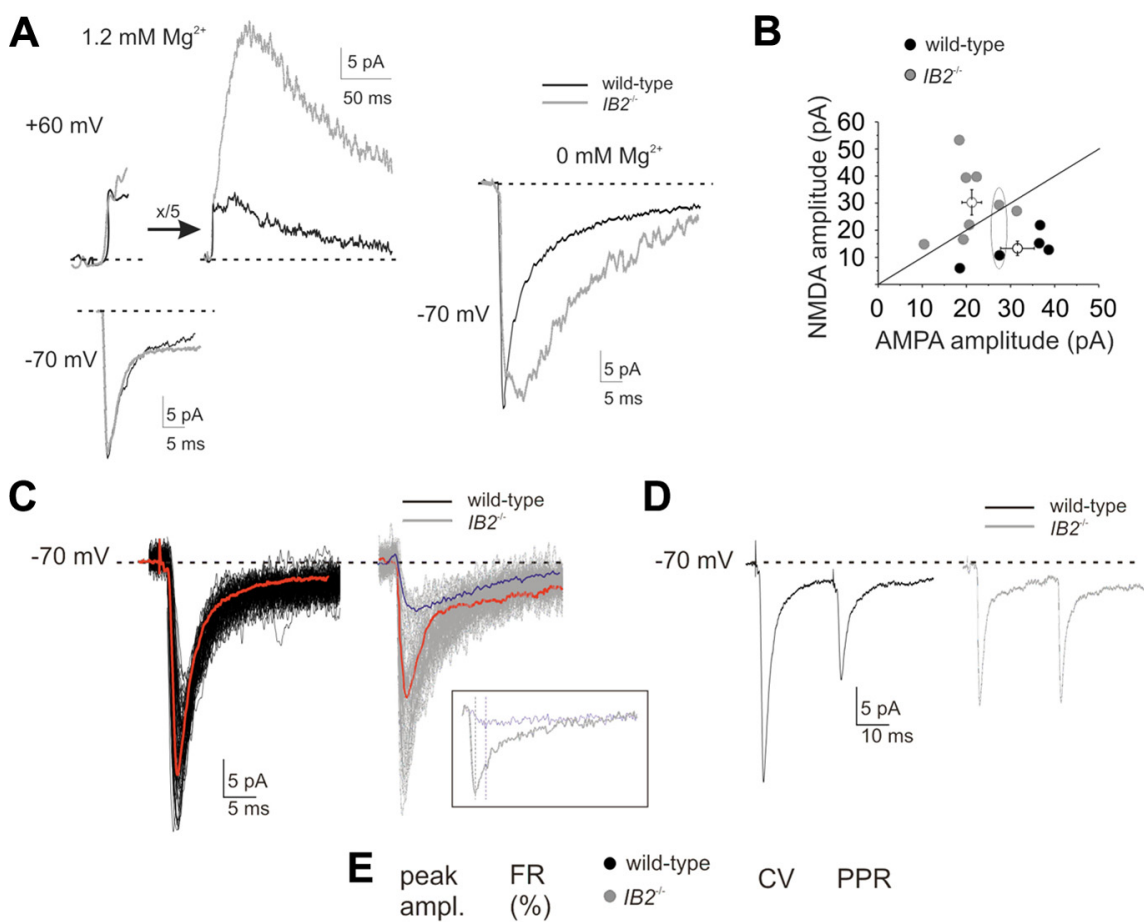

Figure 6. Altered transmission at IB2 - / - cerebellar mossy fiber- granule cell synapses. A, Increased NMDA/AMPA ratio of EPSCS at mossy fiber-granule cell synapses in IB2 - / - compared to wild-type mice. Mean EPSC traces for AMPA and NMDA receptor-mediated currents recorded at $-70 \mathrm{mV} /+60 \mathrm{mV}$ in the presence of $1.2 \mathrm{~mm} \mathrm{Mg}^{2+}$ (left) and at $-70 \mathrm{mV} \mathrm{in} \mathrm{Mg}^{2+}$-free extracellular solution (right). In the left panel, the two cells have been selected to have similar AMPA currents at $-70 \mathrm{mV}$ to facilitate comparison of the NMDA currents. The EPSCs at $+60 \mathrm{mV}$ are shown on reduced time scale to illustrate the NMDA currents. The black and gray lines indicate current traces from wild-type and IB2 - / - mice. $B$, Increased EPSC ${ }_{\text {NMDA }}$ and decreased EPSC $C_{A M P A}$ at IB2 - / - synapses. The amplitude of EPSC $_{\text {NMDA }}$ and EPSC $C_{A M P A}$ for each recorded cell in wild-type (black) and IB2 - / - (gray) mice are plotted for comparison. Open circles with brackets represent mean $\pm S D$ of synapses of each genotype. EPSC $C_{\mathrm{NMDA}}$ at IB2 - / - synapses is on average more than double of that measured at wild-type synapses, while EPSC $_{\text {AMPA }}$ is reduced $\sim 30 \%$ in the mutant (also see supplemental Table 1, available at www.jneurosci.org as supplemental material). The oval encloses the wild-type cell and mutant cell depicted on left in $\boldsymbol{A}$. C, Minimal EPSC recordings at $-70 \mathrm{mV}$. The AMPA current, despite similar maximum amplitude, shows higher variation and more failures (indicated by persistence of indirect component) in IB2 - / - (gray traces) than in wild-type (black traces) mice. Red traces are averages of the corresponding 50 individual responses, while the blue trace is the average of the indirect responses in $I B 2-/-$ only (no indirect responses are present in this particular wild-type recording). The inset shows an IB2-/- individual EPSC composite response (gray) or indirect response only (blue). Note that the indirect response is slower than the direct response (dashed lines indicate the time of peak). D, AMPA EPSCs undergo less pairedpulse depression in IB2 - / - than in wild-type mice. The average of $100 \mathrm{EPSC}$ traces recorded at $-70 \mathrm{mV}$ for paired stimuli with $30 \mathrm{~ms}$ interpulse interval is shown. $E$, AMPA EPSCs from all cells recorded at $-70 \mathrm{mV}$ are presented as scatter plots showing average EPSC peak amplitude, FR, CV, and paired-pulse ratio (PPR) for IB2 - /- (gray) and wild-type (black) mice. The white circles represent mean \pm SEM of the points reported in the plots. See accompanying data summaries in supplemental Table 2 (available at www.jneurosci.org as supplemental material).

the entire thickness of the molecular layer. To test whether molecular layers in mutant cerebella were thinner overall, measurements were made from midline sagittal vermis histological sections. Indeed, molecular layers in lobules 3 and 4 of IB2 - / - cerebella were significantly thinner than those of wild-type (wild-type: $122 \pm 11 \mu \mathrm{m}, n=5$ vs $I B 2-/-: 101 \pm$ $10 \mu \mathrm{m}, n=5, P<0.02$ ). As Purkinje cell dendrites constitute a significant percentage of total molecular layer mass, it is likely that thinner dendrites contribute to the thinner molecular layers in IB2- - - cerebella. 
A

Wild Type

B

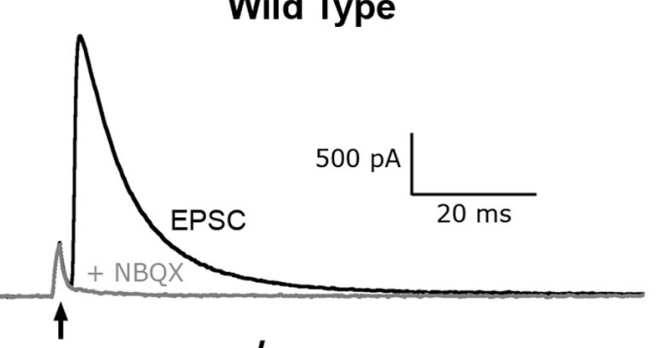

IB2 $^{-I-}$ (normal synapse, 53\%)

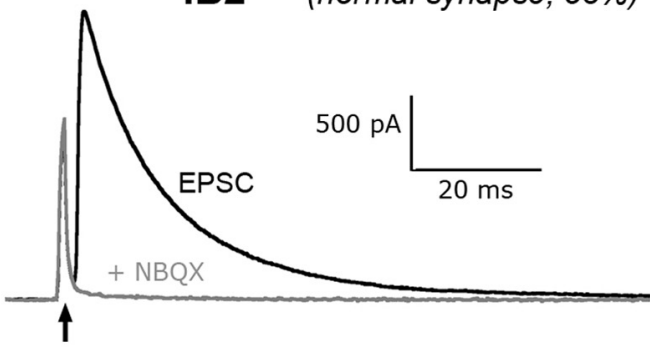

C

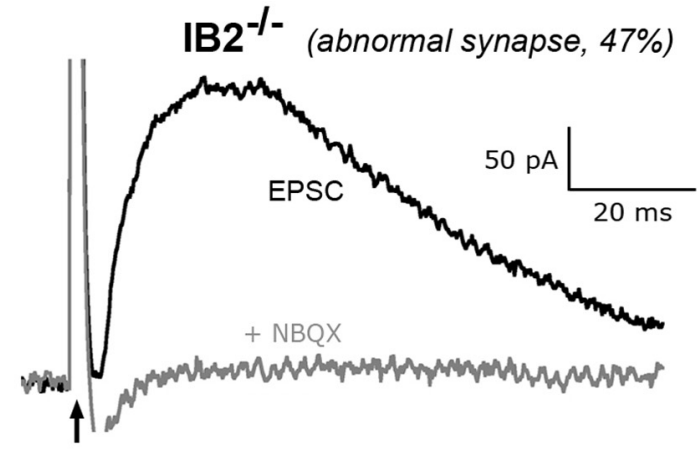

D

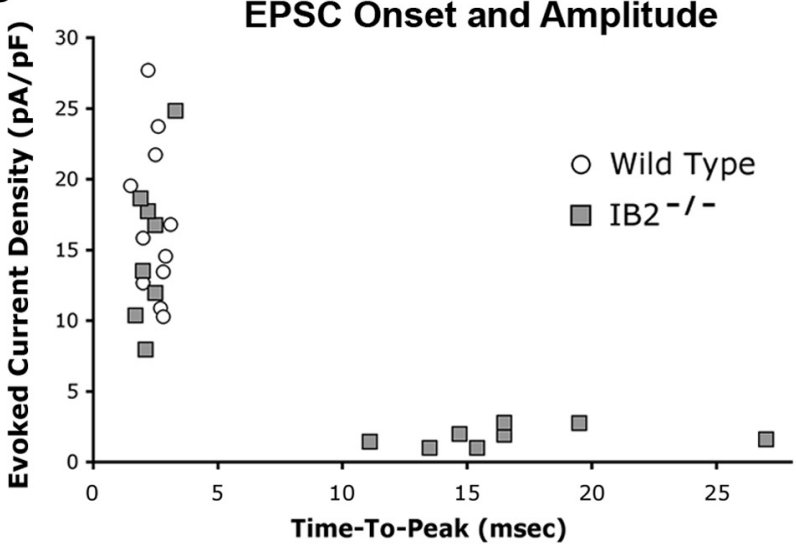

Figure 7. Altered transmission at IB2 - / - cerebellar climbing fiber-Purkinje cell synapses. Purkinje cells were whole-cell patched using pipettes filled with CsCl-based solution containing $2 \mathrm{mM} Q X-314$. All-or-nothing EPSCS were recorded following climbing fiber stimulation while voltage clamping cells at $+40 \mathrm{mV}$; under these conditions, AMPA/ kainate-evoked currents were outward, NMDA currents (if any) were suppressed, and voltage-gated calcium currents were also suppressed by inactivation. $\boldsymbol{A}$, Wild-type Purkinje cell climbing fiber-evoked EPSC has large amplitude and rapid onset and decay, and current is fully blocked by bath perfusion with NBQX. $B, A n I B 2-/-$ Purkinje cell EPSC representative of $53 \%$ ( 9 of 17 ) recorded cells shows normal amplitude and kinetics. $C$, IB2-/- Purkinje cell EPSC representative of $47 \%$ (8 of 17) recorded cells is anomalously small and delayed (note different current scale). $\boldsymbol{D}$, In a plot of EPSC density versus timeto-peak for all recorded Purkinje cells, IB2 - / - cells fall into either normal or anomalous response classes. See accompanying data summaries in supplemental Table 3 (available at www.jneurosci.org as supplemental material).
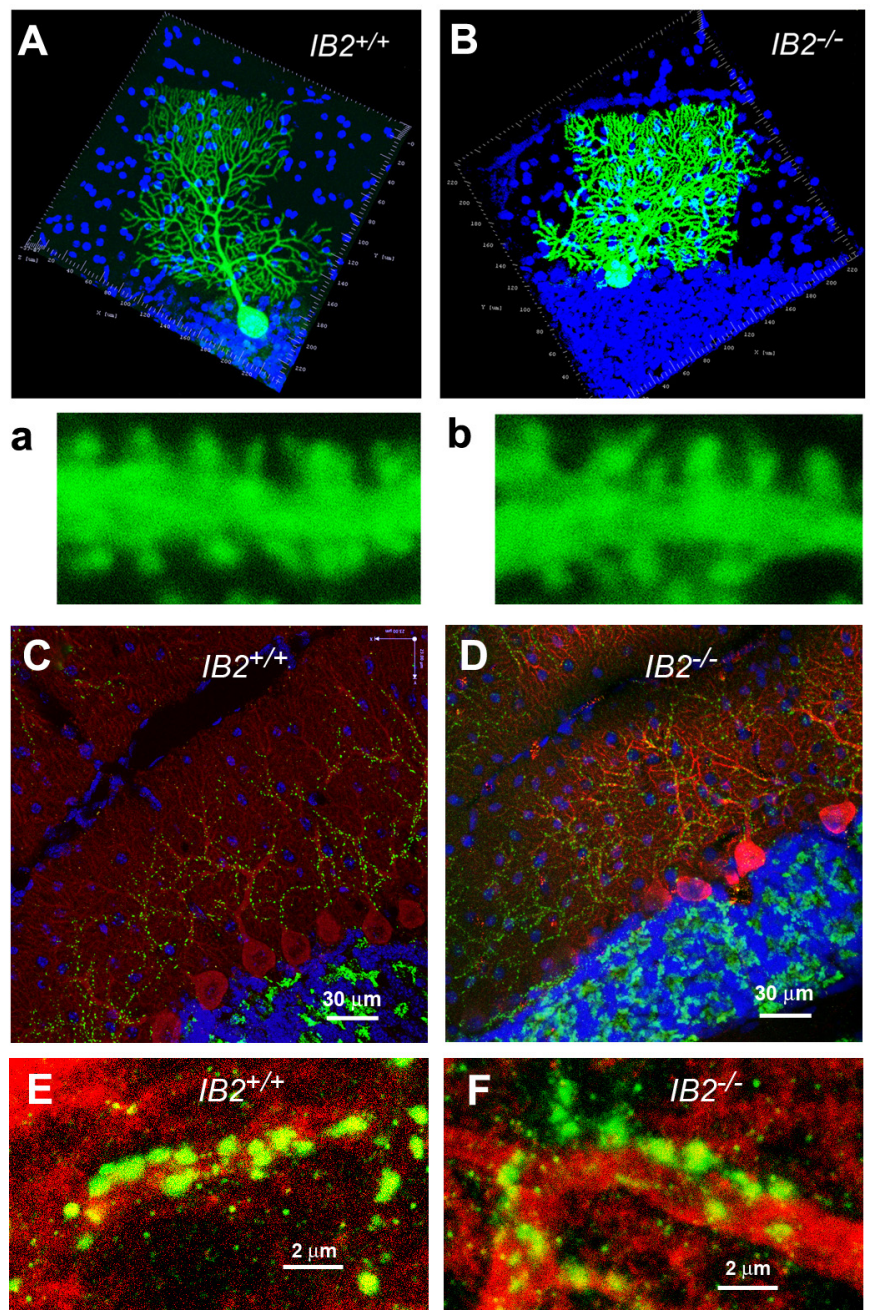

Figure 8. Altered Purkinje cell morphology and normal climbing fiber innervation in IB2 - / - cerebella. $A, \boldsymbol{a}, \boldsymbol{B}, \boldsymbol{b}$, Individual Purkinje cells in sagittal slices of cerebellar vermis were filled with biocytin-Oregon Green by diffusion from a whole-cell patch pipette. Serial stacks of $40 \times$ magnification confocal fluorescent images were used for three-dimensional reconstruction of the entire dendritic arbors $(\boldsymbol{A}, \boldsymbol{B})$, while $1000 \times$ magnification imaging was used to view dendritic spines $(\boldsymbol{a}, \boldsymbol{b})$. The IB2- - - cell's arbor is shorter in height $(\boldsymbol{A})$, likely reflecting lesser intracellular dendritic volume (supplemental Table 4, available at www.jneurosci.org as supplemental material) and reduced overall thickness of the cerebellar molecular layer. The density of spines $(\boldsymbol{a})$ on IB2 - / - dendrites is normal (and supplemental Table 4, available at www. jneurosci.org as supplemental material). $(-\boldsymbol{F}$, Detection of cerebellar climbing fiber varicosities. Cryosections were immunostained for climbing fiber-specific glutamate vesicular transporter VGluT2 (green) and Purkinje cell marker calbindin (red), and costained with nuclear marker TOPRO iodide (blue pseudocolor). In confocal fluorescent image stacks at $63 \times$ magnification, wild-type $(\boldsymbol{C})$ and $I B 2-/-(D)$ climbing fiber varicosities are seen to project along Purkinje arbors extending through much of, but not the entire, molecular layer, and imaging at higher magnification shows examples of varicosities decorating wild-type $(\boldsymbol{E})$ and mutant $(\boldsymbol{F})$ dendrites.

Climbing fiber innervation of Purkinje cells was analyzed by double labeling immunofluorescence, using calbindin antibody to detect Purkinje cells and VGluT2 antibodies to detect varicosities along innervating climbing fibers (Fremeau et al., 2001; Nishiyama et al., 2007). As previously described, wild-type climbing fibers project along Purkinje cell dendritic arbors $75-80 \%$ of the distance from Purkinje soma to the pial layer (Fig. 8C) and have presynaptic varicosities distributed along the thicker dendritic branches (Fig. $8 D$ ). IB2-/- fibers displayed a similar degree of projection through the molecular layer (Fig. $8 E$ ) and varicosity decoration of dendrites (Fig. $8 F$ ). Furthermore, nearly 
all mutant Purkinje cell arbors showed VGluT2-positive climbing fiber innervation (data not shown). These data demonstrate that morphological differences in IB2-/- Purkinje cells and their climbing fibers are not sufficient to account for severe transmission deficits observed in approximately half of all mutant synapses.

\section{Discussion}

The IB2 gene has several properties supporting its role in the genetics of autism spectrum disorders. First, IB2 lies within the chr22q13.3 terminal region deleted in some cases of autism and in virtually all cases of Phelan-McDermid syndrome, which is characterized by severe delay in motor skill acquisition along with autism-like symptoms. Second, we show here that IB2 protein is an integral component of the postsynaptic density, as has been shown for several other autism-linked proteins. Third, IB2 protein is required to establish the proper levels of AMPA-type and NMDA-type evoked currents at cerebellar synapses. Loss of $\alpha$-neurexin, an autism-associated protein, also alters glutamatergic current balance, as does an autism-associated neuroligin gene missense mutation (Kattenstroth et al., 2004; Khosravani et al., 2005). Last, we show that mice lacking IB2 have a range of behavioral deficits reminiscent of Phelan-McDermid syndrome and ASD. These include motor developmental delay, reduced social interaction, and aberrant responses to novel environment. While these experiments have characterized deficits associated with total loss of IB2 function, chr22q13.3 terminal deletions appear to result in regional hemizygosity. It remains to be determined whether related functional deficits occur in $I B 2+/-$ mice or in mice hemizygous for IB2 together with neighboring genes, such as SHANK3.

Stimulus-evoked NMDA current at the cerebellar mossy fiber-granule cell synapse is known to be critical for many aspects of granule cell firing. NMDA current is needed for temporal summation of EPSPs and dictates firing frequency when mossy fiber spike inputs are in the $20-100 \mathrm{~Hz}$ range (D'Angelo et al., 1995). This current also mediates both long-term synaptic potentiation and depression at mossy fiber-granule cell synapses (D'Angelo et al., 1999; Mapelli and D'Angelo, 2007). Last, long-term potentiation of granule cell intrinsic excitability triggered by prior highfrequency mossy fiber inputs is NMDA current dependent (Armano et al., 2000). Therefore, the sizably enhanced NMDA current at this synapse in IB2-/-mice (Fig. 6; supplemental Table 2, available at www.jneurosci.org as supplemental material) is expected to have a significant impact on baseline and experiencedependent information processing at the input stage of the cerebellum. Furthermore, the ability of memantine administration to correct the novel environment-induced locomotor deficit in IB2 - / - mice suggests that aberrantly high NMDA transmission in cerebellum or other brain centers may underlie some of the behavioral abnormalities in mutant animals.

How IB2 mutation enhances stimulus-evoked NMDA current remains to be determined. While the ultrastructure and molecular composition of mossy fiber-granule cell synapses appear normal in IB2-/- cerebella, changes to NMDA receptor unitary conductance, receptor distribution within synapses, or the kinetics of released glutamate clearance are potential mechanisms for elevated evoked NMDA current in the mutants. In contrast to our findings, IB2 mutation has been shown by others to reduce NMDA-evoked currents in cultured immature cerebellar granule cells, and this reduction is enhanced in cells bearing disruptions in IB2 and the closely related IB1/JIP1/MAPK8IP1 gene (Kennedy et al., 2007). Reduced NMDA-evoked conductance in cultured neurons from $I B 1-/-I B 2-/-$ mice was attributed to reduced NR1 subunit tyrosine phosphorylation, a key modulator of NMDA receptor unitary conductance (Kennedy et al., 2007). We have failed to detect altered levels of NR1 tyrosine phosphorylation in adult brain extracts of $I B 2-/-$ versus wild-type mice (data not shown). The contrasting effects of IB2 deletion on immature NMDA-evoked current versus mature stimulus-evoked EPSC $_{\mathrm{NMDA}}$ suggest that IB2 controls specific NMDA conductances by distinct mechanisms.

In contrast to NMDA current enhancement, IB2 mutation diminished stimulus-evoked AMPA currents at both mossy fiber-granule cell and climbing fiber-Purkinje cell synapses. Half of tested IB2-/- climbing fiber-Purkinje cell synapses showed EPSCs of only $1 / 10$ the amplitude and $1 / 6$ the rate of onset in comparison to EPSCs at wild-type synapses (Fig. 7; supplemental Table 3, available at www.jneurosci.org as supplemental material). While mutant Purkinje cells have altered dendritic morphology, their innervation by climbing fibers appears normal (Fig. 8), suggesting that presynaptic or postsynaptic aspects of neurotransmission are impaired. As climbing fiber signaling is essential for rotarod baseline performance and learning (RondiReig et al., 1997), IB2-/- deficits in climbing fiber transmission may be sufficient to account for impaired motor performance in these mice. IB2-/- mossy fiber-granule cell relays also displayed reduced AMPA neurotransmission that was largely due to poorer presynaptic glutamate release probability and also, in part, to reduced quantum size (Fig. 6; supplemental Table 2, available at www.jneurosci.org as supplemental material).

The effects of IB2 disruption on both postsynaptic NMDA conductance and presynaptic glutamate release may reflect loss of IB2 signaling mechanisms both at the postsynaptic density, where IB2 is concentrated, and at the presynaptic terminal. Alternatively, the observed complex deficits may in part reflect a cascade of developmental miscues secondary to an earlier loss of IB2 signaling. The signaling pathways required for proper synaptic transmission that are altered by IB2 disruption have not been determined. p38 MAP kinase signaling is a plausible candidate pathway, as IB2 preferentially associates with the p38 subclass of MAP kinases (Schoorlemmer and Goldfarb, 2001, 2002; Buchsbaum et al., 2002; Robidoux et al., 2005), and both presynaptic and postsynaptic p38 signaling are known to regulate synaptic transmission (Derkinderen et al., 2001; Huang et al., 2004; Krapivinsky et al., 2004; Brust et al., 2006; Li et al., 2006). Other possible mechanisms of IB2 action include modulation of src-like kinase activity (Kennedy et al., 2007) or control of macromolecular transport through IB2 association with kinesin (Verhey et al., 2001).

We have shown here that IB2 is essential for proper morphology and synaptic transmission in cerebellum, and that $I B 2-/-$ mice display impaired motor performance and learning. Cerebellar dysfunction may also account for the cognitive deficits in these mutants. Indeed, acerebellar lurcher mutant mice are deficient in exploration of novel objects (Caston et al., 1998), while rats with surgically ablated cerebellar vermis show reduced anxiety and social discrimination (Bobée et al., 2000). Furthermore, reduced novel environment exploration and stereotypy in autistic children correlates with reduced size of the cerebellar vermis (Pierce and Courchesne, 2001). Alternatively, cognitive deficits in IB2-/ - mice could be due to synaptic transmission deficits throughout the brain, reflecting the widespread distribution of IB2 protein. 


\section{References}

Alarcón M, Abrahams BS, Stone JL, Duvall JA, Perederiy JV, Bomar JM, Sebat J, Wigler M, Martin CL, Ledbetter DH, Nelson SF, Cantor RM, Geschwind DH (2008) Linkage, association, and gene-expression analyses identify CNTNAP2 as an autism-susceptibility gene. Am J Hum Genet 82:150-159.

Armano S, Rossi P, Taglietti V, D’Angelo E (2000) Long-term potentiation of intrinsic excitability at the mossy fiber-granule cell synapse of rat cerebellum. J Neurosci 20:5208-5216.

Bauman ML, Kemper TL (2005) Neuroanatomic observations of the brain in autism: a review and future directions. Int J Dev Neurosci 23:183-187.

Belmonte MK, Allen G, Beckel-Mitchener A, Boulanger LM, Carper RA, Webb SJ (2004) Autism and abnormal development of brain connectivity. J Neurosci 24:9228-9231.

Bobée S, Mariette E, Tremblay-Leveau H, Caston J (2000) Effects of early midline cerebellar lesion on cognitive and emotional functions in the rat. Behav Brain Res 112:107-117.

Bourgeron T (2009) A synaptic trek to autism. Curr Opin Neurobiol 19:231-234

Brust TB, Cayabyab FS, Zhou N, MacVicar BA (2006) p38 mitogenactivated protein kinase contributes to adenosine $\mathrm{Al}$ receptor-mediated synaptic depression in area CA1 of the rat hippocampus. J Neurosci 26:12427-12438.

Buchsbaum RJ, Connolly BA, Feig LA (2002) Interaction of Rac exchange factors Tiam1 and Ras-GRF1 with a scaffold for the p38 mitogenactivated protein kinase cascade. Mol Cell Biol 22:4073-4085.

Caston J, Chianale C, Delhaye-Bouchaud N, Mariani J (1998) Role of the cerebellum in exploration behavior. Brain Res 808:232-237.

Cathala L, Brickley S, Cull-Candy S, Farrant M (2003) Maturation of EPSCs and intrinsic membrane properties enhances precision at a cerebellar synapse. J Neurosci 23:6074-6085.

Chez MG, Burton Q, Dowling T, Chang M, Khanna P, Kramer C (2007) Memantine as adjunctive therapy in children diagnosed with autistic spectrum disorders: an observation of initial clinical response and maintenance tolerability. J Child Neurol 22:574-579.

Clements JD (2003) Variance-mean analysis: a simple and reliable approach for investigating synaptic transmission and modulation. J Neurosci Methods 130:115-125.

Clements JD, Silver RA (2000) Unveiling synaptic plasticity: a new graphical and analytical approach. Trends Neurosci 23:105-113.

D’Angelo E, De Filippi G, Rossi P, Taglietti V (1995) Synaptic excitation of individual rat cerebellar granule cells in situ: evidence for the role of NMDA receptors. J Physiol 484:397-413.

D’Angelo E, Rossi P, Armano S, Taglietti V (1999) Evidence for NMDA and mGlu receptor-dependent long-term potentiation of mossy fiber-granule cell transmission in rat cerebellum. J Neurophysiol 81:277-287.

Delahaye A, Toutain A, Aboura A, Dupont C, Tabet AC, Benzacken B, Elion J, Verloes A, Pipiras E, Drunat S (2009) Chromosome 22q13.3 deletion syndrome with a de novo interstitial 22q13.3 cryptic deletion disrupting SHANK3. Eur J Med Genet 52:328-332.

Derkinderen P, Ledent C, Parmentier M, Girault J-A (2001) Cannabinoids activate $\mathrm{p} 38$ mitogen-activated protein kinases through CB1 receptors in hippocampus. J Neurochem 77:957-960.

DiGregorio DA, Nusser Z, Silver RA (2002) Spillover of glutamate onto synaptic AMPA receptors enhances fast transmission at a cerebellar synapse. Neuron 35:521-533.

Durand CM, Betancur C, Boeckers TM, Bockmann J, Chaste P, Fauchereau F, Nygren G, Rastam M, Gillberg IC, Anckarsäter H, Sponheim E, GoubranBotros H, Delorme R, Chabane N, Mouren-Simeoni MC, de Mas P, Bieth E, Rogé B, Héron D, Burglen L, et al. (2007) Mutations in the gene encoding the synaptic scaffolding protein SHANK3 are associated with autism spectrum disorders. Nat Genet 39:25-27.

Etherton MR, Blaiss CA, Powell CM, Südhof TC (2009) Mouse neurexinlalpha deletion causes correlated electrophysiological and behavioral changes consistent with cognitive impairments. Proc Natl Acad Sci U S A 106:17998-18003.

Fremeau RT Jr, Troyer MD, Pahner I, Nygaard GO, Tran CH, Reimer RJ, Bellocchio EE, Fortin D, Storm-Mathisen J, Edwards RH (2001) The expression of vesicular glutamate transporters defines two classes of excitatory synapse. Neuron 31:247-260.

Huang C-C, You J-L, Wu M-Y, Hsu K-S (2004) Rap1-induced p38 mitogen-activated protein kinase activation facilitates AMPA receptor trafficking via the GDI-Rab5 complex. J Biol Chem 279:12286-12292.

Jamain S, Quach H, Betancur C, Råstam M, Colineaux C, Gillberg IC, Soderstrom H, Giros B, Leboyer M, Gillberg C, Bourgeron T, Paris Autism Research International Sibpair (PARIS) Study (2003) Mutations of the $\mathrm{X}$-linked genes encoding neuroligins NLGN3 and NLGN4 are associated with autism. Nat Genet 34:27-29.

Jamain S, Radyushkin K, Hammerschmidt K, Granon S, Boretius S, Varoqueaux F, Ramanantsoa N, Gallego J, Ronnenberg A, Winter D, Frahm J, Fischer J, Bourgeron T, Ehrenreich H, Brose N (2008) Reduced social interaction and ultrasonic communication in a mouse model of monogenic heritable autism. Proc Natl Acad Sci U S A 105:1710-1715.

Just MA, Cherkassky VL, Keller TA, Minshew NJ (2004) Cortical activation and synchronization during sentence comprehension in high-functioning autism: evidence of underconnectivity. Brain 127:1811-1821.

Kattenstroth G, Tantalaki E, Südhof TC, Gottmann K, Missler M (2004) Postsynaptic N-methyl-D-aspartate receptor function requires alphaneurexins. Proc Natl Acad Sci U S A 101:2607-2612.

Kennedy NJ, Martin G, Ehrhardt AG, Cavanagh-Kyros J, Kuan CY, Rakic P, Flavell RA, Treistman SN, Davis RJ (2007) Requirement of JIP scaffold proteins for NMDA-mediated signal transduction. Genes Dev 21:2336-2346.

Khosravani H, Altier C, Zamponi GW, Colicos MA (2005) The Arg473Cysneuroligin-1 mutation modulates NMDA mediated synaptic transmission and receptor distribution in hippocampal neurons. FEBS Lett 579:6587-6594.

Krapivinsky G, Medina I, Krapivinsky L, Gapon S, Clapham DE (2004) SynGAP-MUPP1-CAMKII synaptic complexes regulate p38 MAP kinase activity and NMDA receptor-dependent synaptic AMPA receptor potentiation. Neuron 43:563-574.

Li S, Tian X, Hartley DM, Feig LA (2006) Distinct roles for Ras-guanine nucleotide-releasing factor 1 (Ras-GRF1) and Ras-GRF2 in the induction of long-term potentiation and long-term depression. J Neurosci 26:1721-1729.

Mapelli J, D'Angelo E (2007) The spatial organization of long-term synaptic plasticity at the input stage of cerebellum. J Neurosci 27:1285-1296.

Mapelli L, Rossi P, Nieus T, D’Angelo E (2009) Tonic activation of GABAB receptors reduces release probability at inhibitory connections in the cerebellar glomerulus. J Neurophysiol 101:3089-3099.

McLachlan EM (1978) The statistics of transmitter release at chemical synapses. Int Rev Physiol 17:49-117.

Meyers EN, Lewandoski M, Martin GR (1998) An Fgf8 mutant allelic series generated by Cre- and Flp-mediated recombination. Nat Genet $18: 136-141$.

Moore SJ, Turnpenny P, Quinn A, Glover S, Lloyd DJ, Montgomery T, Dean JC (2000) A clinical study of 57 children with fetal anticonvulsant syndromes. J Med Genet 37:489-497.

Muhle R, Trentacoste SV, Rapin I (2004) The genetics of autism. Pediatrics 113:e472-e486.

Negri S, Oberson A, Steinmann M, Sauser C, Nicod P, Waeber G, Schorderet DF, Bonny C (2000) cDNA cloning and mapping of a novel islet-brain/ JNK-interacting protein. Genomics 64:324-330.

Nishiyama H, Fukaya M, Watanabe M, Linden DJ (2007) Axonal motility and its modulation by activity are branch-type specific in the intact adult cerebellum. Neuron 56:472-487.

O'Gorman S, Fox DT, Wahl GM (1991) Recombinase-mediated gene activation and site-specific integration in mammalian cells. Science 251:1351-1355.

Phillips GR, Huang JK, Wang Y, Tanaka H, Shapiro L, Zhang W, Shan WS, Arndt K, Frank M, Gordon RE, Gawinowicz MA, Zhao Y, Colman DR (2001) The presynaptic particle web: ultrastructure, composition, dissolution, and reconstitution. Neuron 32:63-77.

Pierce K, Courchesne E (2001) Evidence for a cerebellar role in reduced exploration and stereotyped behavior in autism. Biol Psychiatry 49:655-664.

Piochon C, Irinopoulou T, Brusciano D, Bailly Y, Mariani J, Levenes C (2007) NMDA receptor contribution to the climbing fiber response in the adult mouse Purkinje cell. J Neurosci 27:10797-10809.

Prestori F, Rossi P, Bearzatto B, Lainé J, Necchi D, Diwakar S, Schiffmann SN, Axelrad H, D'Angelo E (2008) Altered neuron excitability and synaptic plasticity in the cerebellar granule layer of juvenile prion protein knockout mice with impaired motor control. J Neurosci 28:7091-7103. 
Rasalam AD, Hailey H, Williams JH, Moore SJ, Turnpenny PD, Lloyd DJ, Dean JC (2005) Characteristics of fetal anticonvulsant syndrome associated autistic disorder. Dev Med Child Neurol 47:551-555.

Robidoux J, Cao W, Quan H, Daniel KW, Moukdar F, Bai X, Floering LM, Collins S (2005) Selective activation of mitogen-activated protein (MAP) kinase kinase 3 and p38alpha MAP kinase is essential for cyclic AMP-dependent UCP1 expression in adipocytes. Mol Cell Biol 25:5466-5479.

Rondi-Reig L, Delhaye-Bouchaud N, Mariani J, Caston J (1997) Role of the inferior olivary complex in motor skills and motor learning in the adult rat. Neuroscience 77:955-963.

Rossi P, Sola E, Taglietti V, Borchardt T, Steigerwald F, Utvik JK, Ottersen OP, Köhr G, D'Angelo E (2002) NMDA receptor 2 (NR2) C-terminal control of NR open probability regulates synaptic transmission and plasticity at a cerebellar synapse. J Neurosci 22:9687-9697.

Saviane C, Silver RA (2006) Errors in the estimation of the variance: implications for multiple-probability fluctuation analysis. J Neurosci Methods 153:250-260.

Schoorlemmer J, Goldfarb M (2001) Fibroblast growth factor homologous factors are intracellular signaling proteins. Curr Biol 11:793-797.

Schoorlemmer J, Goldfarb M (2002) Fibroblast growth factor homologous factors and the islet brain-2 scaffold protein regulate activation of a stressactivated protein kinase. J Biol Chem 277:49111-49119.

Sebat J, Lakshmi B, Malhotra D, Troge J, Lese-Martin C, Walsh T, Yamrom B, Yoon S, Krasnitz A, Kendall J, Leotta A, Pai D, Zhang R, Lee YH, Hicks J, Spence SJ, Lee AT, Puura K, Lehtimäki T, Ledbetter D, et al. (2007) Strong association of de novo copy number mutations with autism. Science 316:445-449.

Sola E, Prestori F, Rossi P, Taglietti V, D’Angelo E (2004) Increased neurotransmitter release during long-term potentiation at mossy fibre-granule cell synapses in rat cerebellum. J Physiol 557:843-861.

Stockinger W, Brandes C, Fasching D, Hermann M, Gotthardt M, Herz J, Schneider WJ, Nimpf J (2000) The reelin receptor ApoER2 recruits JNK-interacting proteins-1 and -2. J Biol Chem 275:25625-25632.
Szatmari P, Paterson AD, Zwaigenbaum L, Roberts W, Brian J, Liu XQ, Vincent JB, Skaug JL, Thompson AP, Senman L, Feuk L, Qian C, Bryson SE, Jones MB, Marshall CR, Scherer SW, Vieland VJ, Bartlett C, Mangin LV, Goedken R, et al. (2007) Mapping autism risk loci using genetic linkage and chromosomal rearrangements. Nat Genet 39:319-328.

Tabuchi K, Blundell J, Etherton MR, Hammer RE, Liu X, Powell CM, Südhof TC (2007) A neuroligin-3 mutation implicated in autism increases inhibitory synaptic transmission in mice. Science 318:71-76.

Taru H, Iijima K, Hase M, Kirino Y, Yagi Y, Suzuki T (2002) Interaction of Alzheimer's $\beta$-amyloid precursor family proteins with scaffold proteins of the JNK signaling cascade. J Biol Chem 277:20070-20078.

Urbanski MJ, Kovacs FE, Szabo B (2010) Endocannabinoid-mediated synaptically evoked suppression of GABAergic transmission in the cerebellar cortex. Neuroscience 169:1268-1278.

Verhey KJ, Meyer D, Deehan R, Blenis J, Schnapp BJ, Rapoport TA, Margolis B (2001) Cargo of kinesin identified as JIP scaffolding proteins and associated signaling molecules. J Cell Biol 152:959-970.

Viennot F, Artault JC, Tholey G, De Barry J, Gombos G (1991) An improved method for the preparation of rat cerebellar glomeruli. J Neurosci Methods 38:51-62.

Wilson HL, Wong AC, Shaw SR, Tse WY, Stapleton GA, Phelan MC, Hu S, Marshall J, McDermid HE (2003) Molecular characterisation of the $22 \mathrm{q} 13$ deletion syndrome supports the role of haploinsufficiency of SHANK3/PROSAP2 in the major neurological symptoms. J Med Genet 40:575-584.

Yasuda J, Whitmarsh AJ, Cavanagh J, Sharma M, Davis RJ (1999) The JIP group of mitogen-activated protein kinase scaffold proteins. Mol Cell Biol 19:7245-7254.

Ye JH, Zhang J, Xiao C, Kong JQ (2006) Patch-clamp studies in the CNS illustrate a simple new method for obtaining viable neurons in rat brain slices: glycerol replacement of $\mathrm{NaCl}$ protects CNS neurons. J Neurosci Methods 158:251-259. 